\section{Drs. de Boysson and Aouba reply}

\section{To the Editor:}

We read with great interest the correspondence from Vitiello and Cammelli ${ }^{1}$, who described their experience on stroke occurring in patients newly diagnosed with giant cell arteritis (GCA). Their observation is concordant with our results, especially regarding the more frequent ophthalmic symptoms, lower biological inflammatory measures, and higher hemoglobin levels in patients with stroke ${ }^{2}$. Additionally, they observed more frequent large-vessel involvement in patients with stroke. Interestingly, they hypothesized the existence of a different pattern of the disease in these patients with more localized inflammation to the cephalic/supraaortic arterial tree and questioned the potential role of varicella zoster virus (VZV) as an etiological factor for GCA, given its known neurovascular tropism ${ }^{3,4}$. Three interesting points must be discussed.

First, we agree with their statement that GCA is a polymorphic condition with different disease subgroups. For example, we recently showed in another study that a subgroup of GCA patients with large-vessel involvement, less frequent cranial manifestations, and lower inflammatory variables can be individualized ${ }^{5}$. In the study from Brack, et al, these patients showed lower levels of proinflammatory cytokines, especially interleukin (IL)- 1 and IL- $6^{6}$. Proinflammatory cytokines are known to have a potent biological effect on endothelial and smooth muscle cells, resulting in procoagulant activity, neovascularization, matrix deposition, myointimal cell proliferation, and vascular tone regulation ${ }^{7}$. This may explain why different vascular manifestations are observed in GCA. Therefore, further pathophysiological studies are required to better understand these differences and determine whether these disease subgroups warrant different therapeutic management.

Second, in accordance with the first point, although progress has been observed in the understanding of the pathophysiological mechanisms of the disease, the trigger of the inflammatory cascade is unknown. VZV is one of the more debated candidates because it can replicate in arteries and cause giant cell inflammation within vessels resulting in stroke and other arterioveinous damage ${ }^{3}$. However, many studies have produced controversial and poorly reproductive results $8,9,10$. More recently, Muratore, et al failed to demonstrate the implication of VZV in GCA pathogenesis ${ }^{11}$. However, regarding the small subset of patients with GCA who experienced a stroke at the onset of the disease, we totally agree with Vitiello and Cammelli ${ }^{1}$ that it would be interesting to search for a potential role of VZV in these patients, given the ability of the virus to develop a central nervous system vasculopathy in some patients $\mathrm{s}^{3,4}$. Temporal artery biopsy remains the standard in the diagnosis procedure of GCA. Interestingly, because giant cell inflammation of the temporal artery is also described in VZV vasculopathy, it may be challenging to distinguish GCA from VZV-related giant cell vasculopathy, especially in GCA patients with incomplete histologic findings on temporal artery biopsy (e.g., absence of fragmentation of the internal elastic lamina). We actually did not systematically search for VZV DNA in temporal artery biopsies, but such analyses may be planned in future research.

Third, adding acyclovir to corticosteroids may be discussed in some cases of doubtful GCA diagnosis, especially in patients with atypical temporal artery results but with giant cells, or patients with involvement of intradural arterial branches that are deprived of internal elastic lamina. In addition, it may be discussed in other atypical presentations of GCA such as peripheral thrombosis, cranial neuropathy, or severe ophthalmic necrotic involvement that can be manifestations of VZV vasculopathy.

Finally, today we are more prone to consider VZV vasculopathy as a serious challenging differential diagnosis rather than an etiologic form of some stroke presentations in GCA. Other combined clinical, pathological, microbiological, and molecular studies focused on these particular clinical presentations, rather than the whole GCA population, will help clarify the issue.

HUBERT DE BOYSSON, MD, MSc; ACHILLE AOUBA, MD, PhD, Department of Internal Medicine, Caen University Hospital, Caen, France. Address correspondence to Dr. H. de Boysson, Department of Internal Medicine, Caen University Hospital, University of Caen-Normandie, Avenue de la Côte de Nacre, 14000 Caen, France.

E-mail: deboysson-h@chu-caen.fr

\section{REFERENCES}

1. Vitiello G, Cammelli D. Large-vessel involvement and varicella zoster virus vasculopathy in giant cell arteritis-related stroke: something to keep an eye on. J Rheumatol 2017;44:1566-7.

2. de Boysson H, Liozon E, Larivière D, Samson M, Parienti JJ, Boutemy J, et al. Giant cell arteritis-related stroke: a retrospective multicenter case-control study. J Rheumatol 2017;44:297-303.

3. Nagel MA, Cohrs RJ, Mahalingam R, Wellish MC, Forghani B, Schiller A, et al. The varicella zoster virus vasculopathies: clinical, CSF, imaging, and virologic features. Neurology 2008;70:853-60.

4. Amlie-Lofond C, Gilden D. Varicella zoster virus: a common cause of stroke in children and adults. J Stroke Cerebrovasc Dis 2016;25:1561-9.

5. de Boysson H, Lambert M, Liozon E, Boutemy J, Maigné G, Ollivier Y, et al. Giant-cell arteritis without cranial manifestations: working diagnosis of a distinct disease pattern. Medicine 2016;95:e3818.

6. Brack A, Martinez-Taboada V, Stanson A, Goronzy JJ, Weyand CM. Disease pattern in cranial and large-vessel giant cell arteritis. Arthritis Rheum 1999;42:311-7.

7. Cid MC, Font C, Oristrell J, de la Sierra A, Coll-Vinent B, López-Soto A, et al. Association between strong inflammatory response and low risk of developing visual loss and other cranial ischemic complications in giant cell (temporal) arteritis. Arthritis Rheum 1998;41:26-32.

8. Nordborg C, Nordborg E, Petursdottir V, LaGuardia J, Mahalingam $\mathrm{R}$, Wellish $\mathrm{M}$, et al. Search for varicella zoster virus in giant cell arteritis. Ann Neurol 1998;44:413-4.

9. Alvarez-Lafuente R, Fernández-Gutiérrez B, Jover JA, Júdez E, Loza E, Clemente D, et al. Human parvovirus B19, varicella zoster virus, and human herpes virus 6 in temporal artery biopsy specimens of patients with giant cell arteritis: analysis with quantitative real time polymerase chain reaction. Ann Rheum Dis 2005;64:780-2.

10. Gilden D, White T, Khmeleva N, Heintzman A, Choe A, Boyer PJ, et al. Prevalence and distribution of VZV in temporal arteries of patients with giant cell arteritis. Neurology 2015;84:1948-55.

11. Muratore F, Croci S, Tamagnini I, Zerbini A, Bellafiore S, Boiardi $\mathrm{L}$, et al. No detection of varicella-zoster virus in temporal arteries of patients with giant cell arteritis. Semin Arthritis Rheum 2017 Feb 10 (E-pub ahead of print).

J Rheumatol 2017;44:10; doi:10.3899/jrheum.170720 